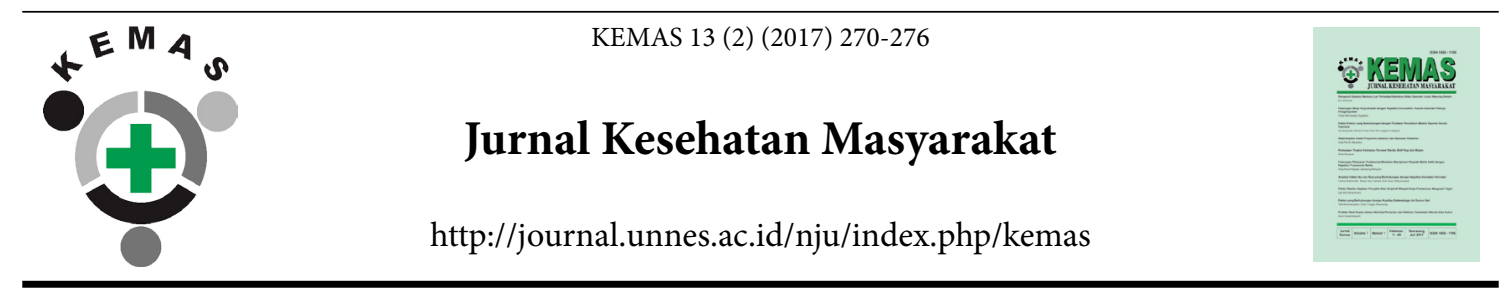

\title{
DETERMINANT OF TEENAGE PREGNANCIES
}

\author{
Elviera Gamelia ${ }^{\bowtie}$, Arif Kurniawan
}

Jurusan Kesehatan Masyarakat, Fakultas Ilmu-Ilmu Kesehatan, Universitas Jenderal Soedirman

\section{Article Info \\ Article History: \\ Submitted Oktober 2016 \\ Accepted November 2017 \\ Published November 2017 \\ Keywords: \\ pregnancy young age; \\ pregnant women; teens \\ DOI \\ http://dx.doi.org/10.15294/ \\ kemas.v13i2.7380}

\begin{abstract}
The number of teenage pregnancies in Banyumas district in 1727 as a pregnant teenager less than 20 years old and young teenagers maternity by 1382 either through premarital or marital. The research was conducted in 2016 aimed to determine the factors that affect pregnancy young age in Banyumas. This research is a quantitative research with cross sectional approach. The population was all pregnant women under 20 years of pregnancy and childbirth are recorded in the data in Puskesmas Jatilawang, Puskesmas I Cilongok, health center II Donates totaled 614 people. Calculation of the estimated proportion of the sample using the formula obtained 107 samples, taken using simple random sampling technique. The data collection is done by using a questionnaire that advance has been tested questionnaire to meet the validity and reliability of a measuring instrument. Yan data analysis used univariate analysis with descriptive statistics, bivariate analysis using chi square, and multivariate analysis by logistic regression. The results showed the level of education, marital status, knowledge, access to information, health care utilization, the role of the family has no effect on pregnancy young age. Attitudes and access to health information is the most dominant variable affecting the pregnancy young age.
\end{abstract}

\section{Introduction}

Based on Indonesian Health and Demographic Survey, in 2012 the national Maternal Mortality Rate (MMR) was 359 per 100.000 living birth. In 2015, the maternal mortality per 100,000 living birth was 111.16 as recorded in Central Java. Maternal Mortality Rate in Banyumas was 100.6 per 100,000 living birth which was still beneath Central Java MMR target, which is 60 per 100.000 living birth (Dinas Kesehatan Kabupaten Banyumas, 2015).

The direct cause of maternal death in Banyumas was obstetric complication (90\%), one of the obstetric complication was younger age for reproduction, under 20 years old, because the reproductive organs weren't mature enough to handle pregnancy and delivery. Based on research data, the younger age of pregnancy has 2-4 times greater risk of maternal death compared to pregnancy in 20-35 years of age. Based on a study by Kurniawan (2017), there was a case of neonatal death from a 17 yearold mother.

The data from Dinas Kesehatan Kabupaten Banyumas recorded 1727 teen pregnancy in below 20 year-olds and 1382 teen birth in unmarried and married teens. The three highest teen pregnancy rate and teen birth rate in primary healthcare in Banyumas were in Puskesmas I Cilongok, Puskesmas II Sumbang, and Puskesmas Jatilawang respectively. The teen pregnancy

\footnotetext{
Correspondence Address:

Jurusan Kesehatan Masyarakat, Fakultas Ilmu-Ilmu Kesehatan,

Universitas Jenderal Soedirman

Email : viera_gamelia@yahoo.com
} 
was also mentioned in a research by Kurniawan et al (2017) which stated that the phenomenon of unmarried teen pregnancy (unwanted pregnancy) happens at a young age, under 19 years old. This serves as the reason for teenagers dropping out of school and getting married younger than 20 years old. Based on the research results by Gamelia et al, 2013, that $7.4 \%$ of pregnant women in Puskesmas Ajibarang were under 20 years old. Ginting's Research (2011), stated that pregnancy-related knowledge, attitudes and behaviors are associated with teen pregnancy, in addition to parental education and occupation. Environmental factors, like culture, also take a role in the occurrence of young pregnancy. Based on the research by Fiatin (2011), patriarchal culture in a community places girls in the domestic sector, making them choose to marry off girls at a young age. This study aims to determine the factors that affect young pregnancy in Banyumas regency.

\section{Method}

This research is a quantitative research with cross sectional approach. The independent variables consisted of education level, marital status, knowledge, access to information, utilization of health service and family role and the dependent variable is teen pregnancy. The population of this study were all adolescents under 20 years old with pregnancy and history of maternity recorded in Puskesmas Jatilawang, Puskesmas I Cilongok and Puskesmas II Sumbang in Banyumas Regency with a total number of 614 people. The sample calculation using estimate proportion formula obtained 107 samples, taken using simple random sampling technique. The inclusion criteria were willing to be respondents, while exclusion criteria were adolescents who did not live in Puskesmas Jatilawang, Puskesmas I Cilongok and Puskesmas II Sumbang work area. Data collection was done using questionnaires (structured question) with interview method which has been tested first to fulfill the validity and reliability of a measuring instrument. The data analysis used was univariate analysis with descriptive statistic which aimed to explain and describe the characteristics of each research variable. Bivariate analysis was conducted to find out the relationship between free variable and dependent variable by using Chi Square test which shows a significant correlation if $\mathrm{p}$-value $\leq 0.05$. Multivariate analysis was used to find out the relationship of more than one independent variable with dependent variable and to know the most dominant variable by using multiple logistic regression test.

\section{Result and Discussion}

From the study we found the teen pregnancy characteristic in Banyumas as follows in Table 1.

From table 1 we knew that most of the respondents were 19 years old $(47.7 \%)$ when pregnant, unemployed (86.9\%), had low family income (59.8\%), had first pregnancy at 18 years old $(42.1 \%)$, and had good pregnancy history $(87.9 \%)$.

The measured criteria for teen pregnancy is when pregnancy occurs at young age whether planned or unwanted. From the research results data was obtained as follows.

Based on Table 2, the results of the univariate analysis showed that most of the respondents had planned young pregnancies (72\%), had not graduated from elementary education (85\%), married (98.1\%), good knowledge level (57\%), bad attitude (61.7\%), good access to health information (57.9\%), good health service utilization (84.1\%), and good family support (52.3\%).

Factors affecting teen pregnancy were analyzed one by one in bivariate analysis. The independent variables used were the level of education, marital status, knowledge, attitude, access to health information, food quality, and parenting. While the dependent variable was teen pregnancy.

From chi-square test result we know the relation of these independent variables with teen pregnancy, shown in Table 3.

Based on Table 3 showed a significant correlation between knowledge with teen pregnancy (0.001), attitude with teen pregnancy (0.001), health information access with teen pregnancy (0.001), and utilization of health service with teen pregnancy (0.037). There is no correlation between educational background with teen pregnancy (1.00), marital status with teen pregnancy (0.077), and parenting with teen pregnancy $(0.438)$.

The results of this study indicated a 
Table 1. Teen Pregnancy Characteristic in Banyumas

\begin{tabular}{|c|c|c|c|c|}
\hline No & Characteristic & Category & $\mathrm{f}$ (people) & Percentage (\%) \\
\hline \multirow[t]{5}{*}{1} & Age & 15 & 1 & 0.9 \\
\hline & & 16 & 5 & 4.7 \\
\hline & & 17 & 9 & 8.4 \\
\hline & & 18 & 41 & 38.3 \\
\hline & & 19 & 51 & 47.7 \\
\hline \multirow[t]{2}{*}{2} & Job & Employed & 14 & 13.1 \\
\hline & & Unemployed & 93 & 86.9 \\
\hline \multirow[t]{2}{*}{3} & Family income & High & 43 & 40.2 \\
\hline & & Low & 64 & 59.8 \\
\hline \multirow[t]{5}{*}{4} & First pregnancy age & 15 & 7 & 6.5 \\
\hline & & 16 & 11 & 10.3 \\
\hline & & 17 & 22 & 20.6 \\
\hline & & 18 & 45 & 42.1 \\
\hline & & 19 & 22 & 20.6 \\
\hline \multirow[t]{2}{*}{5} & Pregnancy history & Good & 94 & 87.9 \\
\hline & & Poor & 13 & 12.1 \\
\hline
\end{tabular}

Source: processed primary data

Table 2. Univariate Analysis

\begin{tabular}{lllll}
\hline No & Variable & Category & $\mathrm{f}$ (people) & Percentage (\%) \\
\hline 1 & Education & Non graduated elementary & 1 & 0.9 \\
& & Elementary School & 90 & 84.1 \\
& & High School & 16 & 15 \\
2 & Marital Status & Married & 105 & 98.1 \\
& & Unmarried & 2 & 1.9 \\
3 & Knowledge & Good & 61 & 57 \\
& & Poor & 46 & 43 \\
4 & Attitude & Good & 41 & 38.3 \\
& & Bad & 66 & 61.7 \\
5 & Information Access & Good & 62 & 57.9 \\
& & Poor & 45 & 42.1 \\
6 & Health care utilization & Good & 90 & 84.1 \\
& & Poor & 17 & 15.9 \\
7 & Parenting & Good & 56 & 52.3 \\
& & Poor & 51 & 47.7 \\
8 & Teen pregnancy & Planned & 77 & 72 \\
& & Unwanted & 30 & 28 \\
\hline
\end{tabular}

correlation between knowledge and teen Imamura's (2007) study showed that healthcare pregnancy (0.001), attitude and teen pregnancy access is a consistent protective factor, whereas (0.001), access to information and teen risk-taking behavior and lifestyle, sexual health pregnancy (0.001), and health care utilization knowledge, attitudes and behaviors were and teen pregnancy $(0.037)$. The results of unclear. The findings of this study indicated 
Table 3. Bivariate Analysis

\begin{tabular}{|c|c|c|c|c|c|c|c|}
\hline \multirow{3}{*}{ Variable } & \multicolumn{4}{|c|}{ Teen Pregnancy } & \multirow{2}{*}{\multicolumn{2}{|c|}{ Total }} & \multirow{3}{*}{ p-value } \\
\hline & \multicolumn{2}{|c|}{ Planned } & \multicolumn{2}{|l|}{ Unwanted } & & & \\
\hline & Quantity & $\%$ & Quantitty & $\%$ & Quantity & $\%$ & \\
\hline \multicolumn{8}{|l|}{$\begin{array}{l}\text { Educational } \\
\text { Background }\end{array}$} \\
\hline High School & 12 & 75 & 4 & 25 & 16 & 100.0 & \multirow[b]{2}{*}{1.00} \\
\hline $\begin{array}{l}\text { Ungraduated and } \\
\text { Elementary }\end{array}$ & 65 & 71.4 & 26 & 28.6 & 91 & 100.0 & \\
\hline \multicolumn{8}{|l|}{ Marital Status } \\
\hline Married & 77 & 73.3 & 28 & 26.7 & 105 & 100.0 & \multirow{2}{*}{0.077} \\
\hline Unmarried & 0 & 0 & 2 & 100 & 2 & 100.0 & \\
\hline \multicolumn{8}{|l|}{ Knowledge } \\
\hline Good & 34 & 55.7 & 27 & 44.3 & 61 & 100.0 & \multirow{2}{*}{0.00} \\
\hline Poor & 43 & 93.5 & 3 & 6.5 & 46 & 100.0 & \\
\hline \multicolumn{8}{|l|}{ Attitude } \\
\hline Good & 13 & 31.7 & 28 & 68.3 & 41 & 100.0 & \multirow{2}{*}{0.00} \\
\hline $\mathrm{Bad}$ & 64 & 97 & 2 & 3 & 66 & 100.0 & \\
\hline \multicolumn{8}{|l|}{$\begin{array}{l}\text { Health Information } \\
\text { Access }\end{array}$} \\
\hline Good & 34 & 54.8 & 28 & 45.2 & 62 & 100.0 & \multirow{2}{*}{0.00} \\
\hline Poor & 43 & 95.6 & 2 & 4.4 & 45 & 100.0 & \\
\hline \multicolumn{8}{|l|}{$\begin{array}{l}\text { Health Care } \\
\text { Utilization }\end{array}$} \\
\hline Good & 61 & 67.8 & 29 & 32.2 & 90 & 100.0 & \multirow{2}{*}{0.037} \\
\hline Poor & 16 & 94.1 & 1 & 5.9 & 17 & 100.0 & \\
\hline \multicolumn{8}{|l|}{ Parenting } \\
\hline Good & 38 & 67.9 & 18 & 32.1 & 56 & 100.0 & \multirow{2}{*}{0.438} \\
\hline Poor & 39 & 76.5 & 21 & 23.5 & 51 & 100.0 & \\
\hline
\end{tabular}

Note: ${ }^{*} p \leq 0.05$

Source: processed primary data

that all these factors interacted with each other. Raj's research (2007) proved that the basic knowledge of adolescents about sexual health is still low, but rarely applied. Utilization of health services to be a protective factor was still low and consistent.

Macleod (2010), explained the factors contributing to teen pregnancies in South Africa which supported the outcome of this study were reproductive system ignorance, risky behavior and poor health, early onset of menarche, psychological problems, peer influence, sexual coercion, dysfunctional family patterns, and poor health service. Thobejane (2015), stated in his research, teen pregnancy in Matjitjileng village, Mogalakwena sub-rural area, South Africa were an impact from risky behavior due to influence from their peers who were pregnant at young age and ignorance of contraception. Mutanana's (2015) study, showed contributing factors to teenage pregnancy in rural communities from Zimbabwe were the influence of peers, lack of sex education, no use of contraceptives, tradition, and low selfesteem.

Nguyen (2016), stated in his research that the prevalence of teen pregnancies in Vietnam were women aged 14 to 19 , and variables that were positively correlated were age, experience of domestic violence and early sexual behavior. Van Eijk (2015), said that the problem of teen pregnancy was an important issue in 
the Cook Islands, teen pregnancy in Cook Islands is caused by their knowledge, attitude and access to information about reproductive health. Utilization of available RH information becomes the focus of approach to tackle teen pregnancy problems in the hope that it would change their knowledge and attitude. Teen pregnancy in sub-Saharan Africa stated that teen pregnancy is associated with a community level of poverty, unemployment, and lack of understanding about teen pregnancy in subSaharan Africa.

The result of this study shows no correlation between educational background (1.00), marital status (0.077), and parenting with teen pregnancy $(0.438)$.

A study by Odejimi (2014), showed that literacy rates, contraceptive prevalence rates and health care spending rates were factors affecting teenage pregnancy. The results of logistic regression analysis in the study showed that literacy rate became the best predictor of teenage pregnancy in Africa. Mutanana's (2015) study, showed contributing factors to teenage pregnancy in rural communities from Zimbabwe is socio-economic background, and low levels of education. Nguyen (2016), stated in his research the variables of education level, and sexual education in schools are significantly related to teenage pregnancy.

This is not in accordance with the results of this study which indicated that education level is not related to teen pregnancy. A possible factor to disrupt the education level variables in this variable is that there is no significant difference in the level of knowledge of reproductive health between different levels of education. This is because health is not a separate subject taught in lower formal education in Indonesia. The results also showed no relationship between marital status and teenage pregnancy. This is because almost all respondents who had registered or religious marriage still have young pregnancy. This was influenced by the role of parents which meant that the respondents come from a good family made up as much as $52.3 \%$, with $47.7 \%$ of respondents did not have a good family role.

Thobejane (2015) stated in his research, teenage pregnancy in Matjitjileng village, Mogalakwena sub-rural area, South Africa happened due to the lack of guidance and role model of teenage parents in the village. Domenico (2007), stated that factors affecting teenage pregnancy were age when having first sexual intercourse, family structure, and parents' roles, which was the most significant factor in the prevention of pregnancy. This is also reinforced in the study by Goicolea (2009), suggesting that factors associated with an increased risk of teenage pregnancy through multivariate analysis were sexual harassment experienced in childhood, early sexual behavior, parental roles and household poverty.

Multivariate analysis was performed to determine the association of independent variable with dependent variable (teen pregnancy), predicting the effect of free variable on teen pregnancy and to know the most influential variable to teen pregnancy. By using logistic regression from selected variable (variable in bivariate analysis with value of Omnibus Tests of Model Coefficients) variables with $\mathrm{p}$ value $<0.25$ were marital status, knowledge, attitude, access to health information and health service utilization.

The results of this study showed that the attitude was the most influential factor in teen pregnancy. The results showed that most of the adolescents had an unfavorable attitude (61.7\%). This was in accordance with Azinar's (2013) study, which found that there is a significant influence between attitudes and risky pre-marital sexual behavior. Attitude is the determinant of existence, attitudes began from the perceived knowledge as a good or bad thing, then become internalized into him (Dalimunthe, 2012). Influence of mother's attitude with teen pregnancy was supported by Langille's (2007) research, that one factor that affect teen pregnancy was attitude. Poor attitudes influence the occurrence of young pregnancies. Based on the results of research respondents, those who have the view that teen pregnancy is not a problem that is at $56.1 \%$. Those respondents assume that teen pregnancy does not harm health. This attitude affects the ability of teenagers to take decisions in planning pregnancy after being married at a young age. Access to health information is also a factor affecting younger pregnancies supported by Mouli's (2014) study, which stated that the lack 
of access to health information affects high teen pregnancies.

This requires appropriate intervention to improve adolescent attitudes about teen pregnancies. Teen pregnancy rates were 39\% lower among people receiving interventions than those receiving standardized practice (no intervention). Interventions conducted were early childhood programs and youth development programs, which were appropriate strategies to reduce unwanted teen pregnancies. Interventions aimed at promoting engagement with schools through learning support, improving unhappy childhood experiences through social guidance and support, and enhancing aspirations through career development and work experience. However, none of these approaches directly handle all, community factor, and family-level factors that affect the teenagers to become young parents.

\section{Conclusion}

This study showed that attitude and information access of reproductive health were significant factors towards teen pregnancy rate in Banyumas regency. Factors that were related to teen pregnancy including knowledge, attitude, access to information, and utilization of health services. Factors unrelated to teen pregnancy including education level, marital status, and family roles. The need for special treatment for adolescents to have a good attitude towards teen pregnancy, good knowledge, and improvement access to reproductive health information is available and utilized by adolescents.

\section{References}

Azinar. 2013. Perilaku Seksual Pranikah Berisiko Terhadap Kehamilan Tidak Diinginkan. Jurnal Kemas Unnes, 8 (2) : 153-160

Dalimunthe, Candra Rukmana dan Kristina Nadeak.2012. Tingkat Pengetahuan Pelajar SMA Harapan-1 Medan Tentang Seks Bebas Dengan Risiko HIV/AIDS.E-Journal FK USU, 1(1) : 1-4

Dinas Kesehatan Kabupaten Banyumas. 2015. Laporan Tahunan Kesehatan Ibu dan Anak . P2 Yankes. Banyumas.

Domenico, D.M and Karen, H.J. 2007. Adolescent Pregnancy in America: Causes and Responses. The Journal for Vocational Special Needs Education. 30 (1) : 4-12

Fiatin EF, Mauliyah I, danPitoyo, 2011, Gambaran Pengetahuan Tentang Kesehatan reproduksi dan Kehamilan Resiko Tinggi Pada Ibu Hamil Usia Muda di Wilayah Kerja Puskesmas Kerek Kecamatan Kerek Kabupaten Tuban, Surya, 1(7) :11-17

Gamelia, E., Sistiarani C., dan Masfiah,S., 2013. Determinan Perilaku Perawatan Kehamilan di Wilayah Kerja Puskesmas I Ajibarang. Jurnal Kesehatan Masyarakat Nasional, 8 (3) : 109-114

Ginting dan Wantania, 2011. Pengetahuan, Sikap dan Perilaku Remaja Hamil tentang Kehamilan Remaja di Manado. Buletin IDI Manado, 1:47-59

Goicolea, I., Wulff, M., ohman, A., Sebastian, M.S. 2009. Risk Factor For Pregnancy Among Adolescent Girls in Ecuador's Amazon Basin : A Case Control Study. Rev Panam Salud Publica, 26 (3) : 221-228

Imamura, M., Tucker,J., Hannaford, P., Oliviera da Silva, M., Astin, M., Wynes, L., Bloemenkamp, K.W.M., Jahn, A., Karro, H., Olsen, J., Temmerman, M. 2007. Factor Associated with Teenage Pregnancy in The European Union Countries : A Systematic Review. The European Journal of Public Health, 17 (6) : 630-636.

Kurniawan, A. Sistiarani, C. Hariyadi, B. 2017. Early Detection Of High Risk Pregnancy. Jurnal Kemas Unnes, 12 (2) : 96-103

Langille, D.B. 2007. Teenage Pregnancy : trends, Contributing Factors and The Physician's Role. Canadian Medical Association Journal,176 (11) : 1601-1602.

Macleod, C.I., Tracey, T. 2010. A Decade Later: Follow-Up Review of South African Research on the Consequences of and Contributory Factors in Teen-Aged Pregnancy. African Journal of Psychology, 40 (1) : 18-31

Mouli, V., McCarraher, D.R., Phipis, S.j., Williamson, N.E., Hainsworth, G. 2014. Contraception for Adolescents in Low and middle Income Countries: Needs, Barriers, and Access. Reproductive Health, 11(1) : 1-8

Mutanana, N., and Mutara, G. 2015. Factors Contributing to Teenage Pregnancies in a Rural Community of Zimbabwe.Journal of Biology, Agriculture and Healthcare, 5(14) : 29-34

Nguyen, H., Shiu, C., Farber, N. 2016. Prevalence and Factors Associated with Teen Pregnancy in Vietnam: Results from Two National Surveys. Published Soc. Hist.2016.

Odejimi, O. And Young, D. B. A. 2014. policy pathway to reducing teenage pregnancy in Africa. Journal of Human Growth and Development, 24 (2) : 135-141 
Raj, A.D., Rabi, B., Amudha P., Edwin, V.T., Gyn, C., 2-10. 2007. Factors Associated With Teenage Pregnancy in South Asia : A systematic Review. Health Science Journal, 4(1) : 3-14.

Thobejane. 2015. Factors Contributing to Teenage Pregnancy in South Africa: The Case of Matjitjileng Village Tsoaledi Daniel Thobejane Institute for Gender and Youth
Studies, University of Venda, South Africa. J Sociology SocAnth, 6(2): 273-277

Van Eijk. 2015. Factors Contributing to Teenage Pregnancies in Rarotonga, Cook Islands. Ministry of Health United Nations Population Fund Secretariat of the Pacific Community.UNFPA. 